\title{
MEMBANGUN MANUSIA BERKARAKER RELIGIUS: STUDI ANAK-ANAK TERLANTAR
}

\author{
Humaidi \\ Sekolah Tinggi Filsafat Islam Sadra, Jakarta \\ humaidias97@gmail.com \\ Kirana Fatmawati \\ Sekolah Tinggi Filsafat Islam Sadra, Jakarta \\ kiranamuhammad18@gmail.com
}

\begin{abstract}
ABSTRAK
Kasus penelantaran anak merupakan salah satu problem utama yang menjadi tantangan bangsa Indonesia. Banyak orang tua yang sengaja meninggalkan anaknya di tempat umum maupun di rumah saki. Salah satunya sebabnya karena faktor ekonomi, sosial, keluarga, atau anak tersebut terlahir cacat. Sehingga orang tua tidak ingin merawat anak tersebut. Untuk mengatasi problem tersebut, Yayasan Sayap Ibu Jakarta hadir tidak hanya untuk menampung, merawat, dan mengasuh anak-anak Yayasan juga membina karakter mereka melalui kegiatan keagamaan dan pendidikan etika. Dengan pembinaan tersebut, mereka dapat menjadi pribadi yang berbudi baik, berikap sopan, dan bertanggungjawab, dan dapat menjadi orang yang bermanfaat. Dalam melaksanakan pembinaan, metode yang digunakan adalah melalui pembiasaan, metode disiplin dan metode bercerita. Berdasarkan hasil penelitian yang dilakukan menunjukkan bahwa Yayasan Sayap Ibu Jakarta telah berhasil dalam mendidik dan membangun karakter mereka menjadi manusia yang berkarakter religius. Membina karakater anak-anak melaui nilai-nilai agama dianggap lebih efektif dibandingkan tanpa nilai-nilai agama. Penelitian ini merupakan jenis penelitian kualitatif lapangan, dengan menggunakan metode diskripsi-induktif dan analisis-filosofis. Dalam pengumpulan data-data, peneliti menggunakan teknik observasi, dokumentasi dan wawancara.
\end{abstract}

Keyword: Pembinaan Karakter, Anak Terlantar, Nilai Religius, Toleran, Demokratis.

\section{PENDAHULUAN}

Dalam beberapa penelitian yang telah dilaksanakan, seperti penelitian Darosy Endah Hyoscyamina, ${ }^{1}$ Ani Siti Anisah, ${ }^{2}$ Amran Hassan, Fatimah Yusoof, Khadijah Alavi, ${ }^{3}$ menujukkan bahwa keluarga sangat beperan dalam pembentukan karakter anak. Menurut Indrati Endang Mulyaningsih, ${ }^{4}$ pengaruh orang tua bukan hanya dalam pemebentukan karakter anak, tetapi juga dalam prestasi belajar dan tentunya dalam keberhasilan dalam pendidikannya. Bahkan, menurut Komaruddin Hidayat, bahwa kebahagiaan seseorang -termasuk kebahagiaan

\footnotetext{
${ }^{1}$ Darosy Endah Hyoscyamina, "Peran Keluarga Dalam Membangun Karaker Anak," Marine Mining 10, no. 2 (2011).

2 Ani Siti Anisah, "Pola Asuh Orang Tua Dan Implikasinya Terhadap Pembentukan Karakter Anak," Jurnal Pendidikan Universitas Garut 05, no. 01 (2011): 70-84, https://journal.uniga.ac.id/index.php/JP/article/viewFile/43/43.

${ }^{3}$ Khadijah Alavi Amran Hassan, Fatimah Yusooff, "Pengaruh Faktor Kesepaduan (Kefungsian Keluarga) Dan Kemahiran Keibubapaan Terhadap Kesejahteraan Psikologi Dalam Kalangan Ibu Bapa Dan Anak," Sains Humanika 3, no. 1 (2014): 99-105.

${ }^{4}$ Indrati Endang Mulyaningsih et al., "The Influence of Social Interaction of Family Relationship, Achievement Motivation, and Independent Learning on Learning Achievement," Jurnal Pendidikan Dan Kebudayaan 20, no. 4 (2014): 441-51.
} 
anak-anak- tergantung dari eksistensi keluarganya, yang menurutnya, keluarga menjadi salah satu pilar utama untuk meraih kebahagiaan selain pekerjaan, kmonitas dan teman yang baik. ${ }^{5}$ Berdasarkan pada hasil penelitian di atas, dapat dikatakan bahwa keluarga sangat berpengaruh terhadap tumbuh kembang anak dalam berbagai aspek dan dimensinya, termasuk dalam pengembangan karakter. Semakin besar peran keluarga, maka semakin tumbuh kembang anakanak, dan demikiran juga sebaliknya. Selain keluarga, institusi lain yang sangat berperan dalam pembangunan karakter adalah sekolah dan masyarakat. ${ }^{6}$ Jika ketiganya bersinergi dan bekerjasama dalam pembinaan karakater, maka pembangunan tersebut akan berjalan efektif dan akan menjadi indikator dari karakter sebuah bangsa dan negara.

Sementara itu, berdasarkan pada pada Konvensi Perserikatan Bangsa-Bangsa (PBB) tentang Hak Anak dan Undang-Undang No. 23 tahun 2002 tentang Perlindungan Anak, baik keluarga maupun anak-anak harus dipenuhi hak-haknya dan dapat perlindungan dari negara. Masuk dalam perlindungan yang diatur dalam Undang-Undang adalah pengasuhan alternatif, Kesehatan dan kesejahteraan dasar, pendidikan, waktu luang, kegiatan budaya.

Walaupun secara normatif ideal dan sudah mendapatkan perlindungan secara hukum, tetapi dalam kenyataannya banyak terjadi anak-anak yang tidak diasuh oleh orang tuanya atau dalam arti lain, anak-anak yang ditelantarkan. Dalam kontek Indonesia, kesus anak-anak terlantar menjadi bagian persoalan besar yang dihadapi oleh negara. Berdasarkan data dari Kementerian Sosial Republik Indonesia pada tahun 2011 yang diperoleh dari survei sosial ekonomi nasional (susenas) bahwa anak terlantar, anak balita terlantar dan lanjut usia terlantar sebanyak 7.191.551 jiwa. ${ }^{7}$ Dilansir dari beritasatu.com pada maret 2017, kementerian sosial (Kemsos) menyebut jumlah anak terlantar mencapai 4,1 juta dan jumlah tersebut akan mengalami penambahan. Serta Kemsos menyebutkan sedikitnya 35.000 anak mengalami eksploitasi. ${ }^{8}$

Adapun, data dari Indonesia Police Watch (IPW) pada tanggal 1 Januari 2018, tercatat bahwa sepanjang 2016 terdapat 88 kejadian bayi baru lahir dibuang dan pada tahun 2017 tercatat sebanyak 178 kasus bayi dibuang orang tuanya, kasus tersebut naik 90 kejadian. IPW juga mengurutkan nama-nama provinsi yang paling banyak pembuangan bayi, antara lain: Jakarta (27 kejadian), Jawa Timur (24 kejadian), Jawa Barat (23 kejadian), Aceh (10 kejadian). ${ }^{9}$ IPW juga menambahkan kasus pembuangan bayi sepanjang Januari 2018 di Indonesia yaitu sebanyak 54 kejadian. ${ }^{10}$ Tercatat pada tahun 2018, terdapat 80 orang terlantar termasuk anak terlantar di wilayah DKI Jakarta pada bulan Desember. ${ }^{11}$ Penambahan data diambil dari Dinas Sosial Provinsi Jawa Barat update terakhir 16 Juli 2018, tercatat bahwa penelantaran anak seJawa Barat sebanyak 135.787 kasus anak terlantar. ${ }^{12}$ Kemudian pada tahun 2018-2019 wilayah DKI Jakarta yang terindikasi anak terlantar terdapat 277 lokasi di wilayah Jakarta.

Berdasarkan Undang-Undang NRI 1945 pasal 34 ayat (1) disebutkan secara eksplisit bahwa fakir miskin dan anak terlantar menjadi tanggungjawab negara. Pasal tersebut berbunyi "Fakir miskin dan anak terlantar dipelihara oleh pemerintah". ${ }^{13}$ Makna daripfasal ini adalah bahwa negara harus menjadi pengayom, pelindung dan bertanggungjawab dalam rangka memehuni hak-hak mereka. Bagian dari tanggunjawab tersebut adalah pendidikan, karena pendidikan

\footnotetext{
${ }^{5}$ Komaruddin Hidayat, Psikologi Kebahagiaan: Merawat Bahagia Tiada Akhir (Jakarta: Noura Books, 2015).

${ }^{6}$ Amirulloh Syarbin, "Model Pendidikan Karakter Dalam Keluarga" (Jakarta: PT Elex Media Komputindo, 2014).

${ }^{7}$ Kementerian Sosial Dalam Angka Pembangunan Kesejahteraan Sosial (Jakarta: Kementerian Sosial Republik Indonesia, Pusat Data Dan Informasi Kesejahteraan Sosial, 2012), perpustakaan.bappenas.go.id.

8 “4.1 Juta Anak Terlantar" (Beritasatu.com, 2018).

9 “178 Bayi Dibuang Ke Jalan Sepanjang 2017” (http:tribunnew.com, 2018).

10 “2018, Kasus Pembuangan Bayi Meningkat” (http:medanbisnisdaily.com, 2019).

11 “Dinas Sosial DKI Jakarta, Data Titik Rawan Anak Terlantar Tahun 2018-2019” (http: data.jakarta.go.id, 2019).

12 "Badan Pusat Statistik Provinsi Jawa Barat" (http: jabar.bps.go.id, 2018).

${ }^{13}$ Kabul Budiyono, Pendidikan Pancasila Untuk Perguruan Tinggi (Bandung: Alfabeta, 2016).
} 
merupakan kesejahteraan mendasar yang dibutuhkan anak-anak. Dalam proses pendidikan anak diperlukan adanya bimbingan, pengasuhan, pembinaan kehidupan agama dan sosial. Pendidikan merupakan bekal setiap orang untuk menjalani kehidupan masa depannya. Khoe Yao Tung menyatakan bahwa: "keberhasilan pendidikan suatu bangsa merupakan salah satu barometer keberhasilan pemerintahan suatu negara". ${ }^{14}$ Berangkat dari hal tersebut maka pendidikan merupkan kunci utama dalam meningkatkan kualitas suatu bangsa.

Selain itu, berdasarkan tujuan RI yang tercermin dalam alinea ke 4 pada pembukaan UUD 1945, bahwa Pemerintah Negara Indonesia berkewajiban mencerdaskan kehidupan bangsa, maka pasal 31 ayat (1) menetapkan bahwa tiap-tiap warga negara berhak mendapat pengajaran. ${ }^{15}$ Dengan demikian berarti bahwa semua warga negara Indonesia tanpa terkecuali berhak mendapatkan pendidikan sebagaimana mestinya. Begitupun anak-anak terlantar yang berada di suatu tempat penampungan atau di panti asuhan, mereka berhak mendapatkan pendidikan formal maupun informal terkhusus dalam pembinaan karakter.

Dalam kasus anak-anak terlantar, ada dua problem utama yang secara bersama-sama terdapat pada mereka. Pertama, mereka tidak memiliki keluarga yang dapat dijadikan penopang dan sandaran untuk memenuhi kebutuhan dan hak-haknya. Kedua, persoalan yang terkait dengan pendidikan, pembinaan, dan pembangunan morak, akhlak, dan karakternya. Terkait dengan problem yang kedua, tidak hanya menimpa anak-anak terlantar, tetapi dalam konteks masyarakat secara umum sedang mengalami krisis moral.

Persoalan ini pula -semakin tingginya anak-anak terlantar dan krisis moral- menjadi salah konsern dari Yayasan Sayap Ibu Cabang Jakarta. Pelaksanaan dan tujuan dari penelitian ini adalah dalam rangka mencari solusi dan model dalam, pengasuhan, pembinaan dan pembangunan karakter bagi anak-anak terlantar melalui Yayasan Sayap Ibu Jakarta. Rumusan masalah dalam penelitian ini adalah bagaimana Yayasan Sayap Ibu Jakarta membina anakanak terlantar untuk menjadi pribadi yang baik sesuai dengan nilai-nilai agama.

\section{KAJIAN PUSTAKA}

Undang-Undang RNI 1945, pasal 1 ayat 6, mendefinisikan anak-anak terlantar adalah sebagai berikut; "Anak terlantar adalah anak yang tidak terpenuhi kebutuhannya secara wajar, baik fisik, mental, maupun spiritual. Terlantar disini juga diartikan ketika hak-hak sebagai anak tidak terpenuhi, seperti hak anak dalam memperoleh pendidikan, kesehatan, kasih sayang dan sebagainya. Anak-anak terlantar merupakan individu-individu yang diabaikan haknya oleh orang-orang yang sengaja melepas tanggung jawab, seperti orang tua dan keluarga.

Undang-Undang Nomor 23 Tahun 2002, Tentang Perlindungan Anak Pasal 1, menyatakan bahwa anak adalah seseorang yang belum berusia 18 tahun, termasuk anak yang masih dalam kandungan. Dikatakan juga dalam undang-undang bahwa anak terlantar adalah anak yang tidak terpenuhi kebutuhannya secara wajar, baik itu fisik, mental, spiritual, maupun sosial. Menurut pendapat Robert L. Balker tentang pengertian anak terlantar, ialah "Child Neglect is the failure of those responsible for the care of a minor to provide the resources needed for healthy physical, emotional, and social development. Exemple of neglect include inadequate nutrition, inproper supervison, or no provisions for educational or health care requirements". ${ }^{16}$

Rusmil Kusnandi menjelaskan apabila orang tua tidak dapat memenuhi kebutuhan anak, baik kebutuhan fisik, psikis ataupun emosi, tidak memberikan perhatian dan sarana untuk

\footnotetext{
${ }^{14}$ Daulat P Tampubolon, Perguruan Tinggi Bermutu: Paradigma Baru Management Pendidikan Tinggi Menghadapi Tantangan Abad Ke 21 (Jakarta: PT Gramedia Pustaka Utama, 2001).

${ }^{15}$ Budiyono, Pendidikan Pancasila Untuk Perguruan Tinggi.

${ }^{16}$ Robert L. Balker, The Social Work Dictionary (Washington DC: National Association of Social Workers (NASW) Press, 1999).
} 
berkembang sesuai dengan tugas perkembangannya juga merupakan tindakan penelantaran. ${ }^{17}$ Tindakan tersebut baik disengaja maupun tidak disengajara, adan ada motif maupun tidak ada motif.

Menurut Siti Asysyifa, anak-anak menjadi terlantar karena disebabkan oleh dua faktor utama, yaitu faktor keluarga dan ekonomi. Sebagaimana disebutkan pada sub bab Pendahuluan, bahwa keluarga sangat menentukan tumbuh kembang anak termasuk masa depannya. Demikian juga, dalam kasus terjadinya anak-anak terlantar, keluar menjadi faktor utama. Anak-anak menjadi terlantar karena akibat dari keluarga itu yang disebabkan oleh beberapa persoalan seperti kurang harmonis dan bercerai.

Di samping itu, anak menjadi terlantar karena kelahirannya tidak diinginkan seperti lahir dengan anggota fisik tidak sempurna atau lahir akibat dari bubungan terlarang. ${ }^{18}$ Berdasarkan pengalaman Ibu Atie, pengelola dan pengurus Yayasan Sayap Ibu Jakarata, kasus terjadinya anak-anak terlantar karena biaya persalinan yang cenderung mahal, sehingga menyebabkan para orang tua yang tidak memiliki biaya persalinan untuk menebus anaknya. Efeknya adalah mereka meninggalkan anaknya di rumah sakit. ${ }^{19}$

Sebab yang lain adalah kurangnya kesadaran orang tua (keluarga) terhadap pendidikan. Keluarga merupakan lembaga pendidikan pertama dalam mengaktualisasikan potensipotensinya. Tetapi, jika anak kurang mendapatkan pendidikan dan perhatian dari kedua orangtuanya, maka akan timbul berbagai dampak negatif bagi dirinya. Oleh karena itu, jika orang tua tidak memberikan hak-hak anaknya dalam mendapatkan pendidikan dari orang tua, maka hal itu sama seperti orang tua menelantarkan anaknya.

Faktor kedua yang menjadikan anak-anak terlantar adalah ekonomi. Pendidikan bagi anak sangatlah penting, akan tetapi ekonomi yang tidak mendukung juga menjadi salah satu faktor orang tua kurang memberikan pendidikan bagi anaknya. Sehingga anak ikut terjun ke jalan demi membantu perekonomian keluarganya. ${ }^{20}$ Demikian juga, anak menjadi terlantar rendahnya pendapatan orang tua dan tidak cukup untuk memenuhi kebutuhan sekolah anaknya, seperti membeli baju sekolah, sepatu, tas dan perlengkapan sekolah lainnya yang cenderung mahal. Dampaknya adalah anak lebih memilih untuk terlibat membatu orang tuanya mencukupi kebutuhan ekonomi keluarga. ${ }^{21}$

Ketika anak terlantar, bukan hanya berdampak pada pendidikan dan psikologinya, tetapi juga pada pembangunan karakternya. Karakter, dalam kamus psikologi disebut sebagai bagian dari kepribadian seseorang, ditinjau dari titik tolak etis atau moral, misalnya kejujuran seseorang; biasanya mempunyai kaitan dengan sifat-sifat yang relatif tetap. ${ }^{22}$ Akar kata karakter berasal dari bahasa yunani yang bearti "to mark" atau menandai dan memfokuskan tata cara mengaplikasikan nilai kebaikan dalam bentuk tindakan atau tingkah laku. ${ }^{23}$ Istilah karakter dalam kajian Islam memiliki kesamaan makna dengan akhlak, meskipun beberapa tokoh masih memperdebatkan antara keduanya, namun hal tersebut bukan menjadi persoalan utama dalam kajian ini.

Menurut Puspo Nugroho dalam jurnalnya mendefinisikan bahwa kata akhlak berasal dari bahasa arab yakni "Khuluq", sedangkan kata karakter berasal dari bahasa Yunani yaitu "Kharassein". Kata akhlak lebih sering digunakan pada ruang lingkup keagamaan terutama

\footnotetext{
${ }^{17}$ Eko Setiawan, Nurliana Cipta Apsari, and Santoso Tri Raharjo, "Pengangkatan Anak Balita Terlantar," Sosio Informa 5, no. 1 (2019): 25-37, https://doi.org/10.33007/inf.v5i1.1622.

${ }^{18}$ Siti Asysyifa, Faktor Yang Menyebabkan Penelantaran Anak (Salatiga: Universitas Kristen Satya Wacana, 2017).

${ }^{19}$ Wawancara dengan ibu Sri Harti Yulianti, 15 Maret 2019 (2019).

${ }^{20}$ Asysyifa, Faktor Yang Menyebabkan Penelantaran Anak.

${ }^{21}$ Bagong Suyanto, Masalah Sosial Anak (Jakarta: Kencana Prenada Media Group, 2010).

22 Dali Gulo, Kamus Psikologi (Bandung: Tonis, 1982).

${ }^{23}$ Hamied Hamdani, dkk, Pendidikan Karakter Perspektif Islam (Bandung: Pustaka Setia, 2013).
} 
dalam lingkungan pendidikan Islam, dan kata karakter lebih banyak digunakan secara nasional formal. $^{24}$

Nilai -nilai karakter dan budaya bangsa berasal dari teori-teori pendidikan, nilai-nilai sosial budaya, ajaran agama, psikolog, Pancasila, UUD $1945 .{ }^{25}$ Kementerian Pendidikan Nasional (Kemendiknas) mengidentifikasi 18 macam karakter yang dapat dijaikan nilai dalam membangun pendidikan budaya dan karakter bangsa. ${ }^{26}$ kedelapanbelas karakter tersebut adalah; religius, jujur, toleransi , disiplin ,kerja keras, kreatif , mandiri demokratis, rasa ingin tahu, semangat kebangsaan cinta tanah air menghargai prestasi, bersahabat dan komunikatif, cinta damai ,gemar membaca, peduli lingkungan, peduli sosial, tanggungjawab.

Walaupun karakter dalam pengembangan budaya bangsa diambil dari beragam sumber, tetapi yang paling utama dalam membangun karakter adalah yang berasal dari nilai-nilai agama atau nilai-nilai religius. Nilita-nilai tersebut diartikan sebagai sikap dan perilaku yang patuh dalam melaksanakan ajaran agama yang dianutnya, toleran terhadap pelaksanaan ibadah agama lain, dan selalu hidup rukun dengan pemeluk agama lain. ${ }^{27}$ Dengan kata lain, religius merupakan penghayatan dan pelaksanaan ajaran agama dalam kehidupan sehari-hari. Nilai religius adalah nilai yang bersumber dari keyakinan ketuhanan yang ada pada diri seseorang. ${ }^{28}$ Nilai Ketuhanan ini, dalam konteks bangsa dan negara Indonesia tercantum pada falsafah dan ideologi bangsa, yaitu Pancasila, pada sila pertama, Ketuhanan Yang Maha Esa.

Adapun indikator pembangunan karakter berbasis nilai-nilai agama dalam penelitian ini yang diambil dari Abdul Majid dan Dian Andayana,9 adalah sebagai berikut. Pertama, iman. Keimanan merupakan suatu yang esensial yang harus pertama kali ditanamkan kepada anakanak. Keimanan akan membantuk anak memiliki sandaran dan harapan. Sebelum melakukan aktifitas apapun perlu mengingatkan mereka untuk percaya kepada Tuhan Yang Maha Esa. Kedua adalah takwa,yaitu anak-anak harus dibina bahwa Tuhan selalu mengawasi kita, sehingga ketika mereka melakukan aktifitas diluar bersama teman-temannya maka mereka berusaha untuk berbuat sesuatu hanya karena-Nya.

Ketiga adalah bersyukur. Anak-anak harus memiliki rasa syukur, karena syukur merupakan sikap penuh terima kasih atas segala nikmat yang telah diterimanya. Indikator yang keempat adalah sikap sabar. Anak-anak harus diajarkan untuk memiliki sikap sabar dalam menerima masalah ataupun kesulitan yang dialaminya. Dan indikator kelima adalah memiliki sikap kasih sayang. Indikator yang terakhir diartikan sebagai cinta kasih sayang antara sesama manusia. Sikap ini harus diterapkan kepada anak karena sifat utama Tuhan ialah kasih (rahim, rahman).

\section{METODE PENELITIAN}

Jenis penelitian adalah kualitatif-lapangan (field research). Sumber penelitian yang digunakan dalam penelitian ini digolongkan kepada dua jenis, yaitu data primer dan data sekunder. ${ }^{30}$ Data primer adalah data yang secara langsung berhubungan dengan objek material penelitian, yang

\footnotetext{
${ }^{24}$ Puspo Nugroho, "Internalisasi Nilai-Nilai Karakter Dan Kepribadian Mahasiswa Pendidikan Agama Islam Melalui Pendekatan Humanis-Religius,” Edukasia : Jurnal Penelitian Pendidikan Islam 12, no. 2 (2017): 355 , https://doi.org/10.21043/edukasia.v12i2.2491.

${ }^{25}$ Zubaidi, Desain Pendidikan Karakter: Konsep Dan Aplikasinya Dalam Lembaga Pendidikan (Jakarta: Kencana, 2011).

${ }^{26}$ Wibowo Agus, Pendidikan Karakter: Strategi Membangun Karakter Bangsa Berperadaban (Yogyakarta: Pustaka Pelajar, 2012).

${ }^{27}$ Suyanto, "Urgensi Pendidikan Karakter, Direktorat Pendidikan Dasar Kementrian Pendidikan Nasional,"

Http: Www.Mandikdasmen.Depdiknas.Go.Id, 2019.

${ }^{28}$ Sjarkawi, Pembentukan Kerpibadian Anak (Jakarta: Bumi Aksara, 2008).

${ }^{29}$ Abdul Majid dan Dian Andayani, Pendidikan Karakter Perspektif Islam (Bandung: PT Remaja Rosdakarya, 2011).

${ }^{30}$ Kaelan, Metode Penelitian Agama Kualitatif Interdisipliner (Jogjakarta: Paradigma, 2010).
} 
anak-anak terlantar diasuh oleh Yayasan Sayap Ibu Cabang Jakarta. Dalam penelitian ini yang menjadi data primer adalah keterangan dari anak-anak terlantar, pengelola, dan guru yang ada Yayasan Sayap Ibu Cabang Jakarta. Sedangkan data sekunder adalah data-data yang tidak secara langsung berhubungan dengan objek material sperti buku, artikel jurnal, foto-foto kegiatan, daftar kegiatan, jadwal, dan tulisan-tulisan lain yang terkait dengan tema penelitian ini.

Teknik pengumpulan data melalui tiga tahapan; pertama, observasi langsung di Yayasan Sayap Ibu Cabang Jakarta, Unit Yayasan Sayap Ibu di Cirendeu. Observasi ini dilakukan sebelum dan pada saat proses penelitian. Kedua, pengumpulan data-data yang akan dijadikan sumber rujukan dalam penyusunan instrumen. Ketiga, melakukan wawancara kepada narasumber pokok seperti ketua umum, kepala penanggung jawab tumbuh kembang anak, kepala panti, kepala rumah tangga, guru mengaji, dan anak-anak panti, dengan berpanduan pada daftar wawancara atau instrumen penelitian yang sudah disiapkan.

Proses berikutnya adalah analisa. Proses ini melalui tiga tahapan; pertama, data yang telah terkumpul kemudian direduksi, dirangkum, dan dipilah hal-hal pokok guna memfokuskan penelitian pada hal-hal penting yang sesuai dengan tema dan tujuan penelitian. Setelah proses pertama selesai, maka dilanjutkan apada langkah kedua, yaitu menyusun secara sistematis dan diklasifikasikan sesuai dengan ciri khas dan kategori-kategori yang telah dibuat pada pemetaan penelitian. ${ }^{31}$

\section{HASIL DAN PEMBAHASAN}

Berdasarkan hasil penelitian, menunjukkan bahwa Yayasan Sayap Ibu berhasil menanamkan nilai-nilai religius dan menjadi karakter bagi anak-anak terlantar. Berikut adalah hasil penelitiannnya.

\section{Profil Yayasan Sayap Ibu}

Yayasan Sayap Ibu berdiri pada tanggal 30 september tahun 1955. Tujuan didirikan lembaga tersebut sebagai wujud kepedulian beberapa ibu, diantaranya Ibu Sutomo, terhadap semakin banyaknya bayi ditelantarkan oleh orang tuanya. Sementara itu, di lain pihak ada banyak keluarga yang tidak dapat mempunyai anak. Oleh karena itu, lahirlah pemikiran untuk mendirikan yayasan yang diberi nama, Yayasan Sayap Ibu, dengan tujuan untuk membantu mengatasi masalah tersebut.

Nama Yayayasan Sayap Ibu itu sendiri diambil dari bahasa Belanda yaitu "Onder moeder's vleugels" yang artinya "dibawah sayap ibu". Maksudnya bahwa menggambarkan betapa besar tekad seorang ibu dalam melindungi anaknya, seperti induk ayam yang menggunakan sayapnya untuk melindungi anak-anaknya dari segala bahaya yang dapat menimpanya.

Dalam proses perjalanannya, Yayasan Sayap Ibu sempat mengalami masalah keuangan sehingga harus dihentikan untuk sementara pada tahun 1968. Namun berkat tekad kuat para ibu, terutama ibu J. S. Nasution, Yayasan Sayap Ibu dapat berjalan kembali dan kini bahkan telah berkembang jauh lebih besar. ${ }^{32}$ Visi dari yayasan ini adalah, "Bahwa anak adalah amanah yang berhak akan perawatan dan perlindungan sejak semasa dalam kandungan dan sesudah dilahirkan". ${ }^{33}$ Sedangkan misinya adalah, "Melaksanakan usaha kesejahteraan anak yang holistik terpadu dan berkesinambungan dalam arti yang seluas-luasnya."

\section{Nilai-Nilai Pembinaan Karakter}

\footnotetext{
${ }^{31}$ Muhammad Ali, Memahami Riset Prilaku Sosial (CV Pustaka Cendekia Utama, 2011).

32 "Visi Misi Yayasan Sayap Ibu," http://sayapibujakarta.org, n.d.

33 "Visi Misi Yayasan Sayap Ibu."
} 
Di Yayasan Sayap Ibu Jakarta, pendidikan karakter dilaksanakan secara non formal, yakni anak dibiasakan untuk memiliki perilaku yang sesuai dengan kode etik dan nilai-nilai agama. Artinya bahwa anak dibina bagaimana melatih sopan santun atau tata krama. Pendidikan etika ini diajarkan kepada anak setiap saat, atau dengan kata lain menggunakan metode pembiasaan. Misalnya jika anak hendak pergi ke sekolah maka diajarkan untuk pamit, ataupun ketika bertemu dengan orang-orang diajarkan untuk mengucapkan salam dan senyum. ${ }^{34}$ Kegiatan seperti ini diajarkan agar anak memiliki sikap disiplin, mandiri, jujur, bertanggung jawab, dan toleransi.

Penbinaan karakter anak-anak terlantar di Yayasan Sayap Ibu berbasis nilai religius-nilai, karena sebagaimana dikatakan oleh kepala penanggung jawab tumbuh kembang anak, Sudarno, mayoritas anak-anak di Yayasan Sayap Ibu beragama Islam. ${ }^{35}$ Oleh karena itu, makna nilai-nilai religius di sini adalah berdasarkan prinsip-prinsip dan nilai-nilai keislaman. Selain itu, menurut Masnur Muslich bahwa karakter dimaknai sebagai nilai-nilai perilaku manusia sangat erat kaitannya dengan konsep Ketuhan Yang Maha Esa, diri sendiri, sesama manusia, lingkungan dan kebangsaan yang terwujud dalam pikiran sikap, perasaan, perkataan dan perbuatan. ${ }^{36}$ Sehingga sikap dan perilaku tersebut tidak bisa dilepaskan dsari norma-norma agama, hukum, tatakrama,budaya, dan adat istiadat.

Menurut Sudarno, Yayasan Sayap Ibu dalam hal membina karakter anak-anak menerapkan 18 nilai karakter yang dikeluarkan oleh kemendiknas. Yayasan menekankan bahwa tidak ada yang harus lebih utama, karena semua nilai-nilai tersebut setara dan sama-sama penting sehingga harus diajarkan kepada anak-anak. ${ }^{37}$ Selain itu dalam membina karakter anak-anak tidak dapat dikatakan mudah dan sulit. Namun dalam membina mareka haruslah dengan hati ke hati. ${ }^{38} \mathrm{Hal}$ demikian dilakukan agar anak-anak dapat mengerti dan memahami setiap tindakan, nasehat yang pengasuh berikan.

Salah satu nilai-nilai agama yang diajarkan dan ditanamkan kepada anak-anak adalah juju. Nilai ini merupakan sikap yang harus ditumbuhkan di setiap individu. Dengan jujur, kita dapat diterima oleh lingkungan masyarakat. Begitupula Yayasan Sayap Ibu dalam membina anakanak asuhnya dengan menenamkan karakter jujur. Sikap ini teraktualisasikan dalam keseharian anak-anak yang ada di Yayasan Sayap Ibu. Hal tersebut disampaikan oleh Bu Hari yang mengatakan bahwa ketika anak akan pergi ke luar asrama, baik itu pergi ke masjid, pergi beli jajan di warung atau pergi kegiatan apapun, mereka selalu izin, pamit, dan menjelaskan apa yang akan mereka lakukan. ${ }^{39}$

Nilai dan karakter lain yang berdasarkan pada agama adalah tanggung jawab. Sebagai orang Muslim memiliki kewajiban dan tanggunjawab untuk melakukan shalat, bagi anak-anak yang beragama Islam. Berdasarkan dari hasil penelitian, peneliti menemukan bahwa anak-anak sangat bertanggungjawab dalam melaksanakan tugas dan kewajibannya. Salah satu contohnya adalah kegiatan shalat berjamaah yang secara khusus dilakukan pada hari Jum'at dan Minggu yakni hanya sholat jamaah magrib dan isya'. Pada hari tersebut biasanya dipimpin oleh guru ngajinya untuk menjadi imam.

Tetapi, jika guru ngaji yang memimpin menjadi imam tidak hadir, maka anak-anak tetap melakukan shalat berjamaah dan bergantian untuk menjadi imam shalat untuk temantemannya. ${ }^{40}$ Disinilah anak mengaplikasikan sikap tangggung jawab untuk menjadi imam,

\footnotetext{
${ }^{34}$ Wawancara dengan bapak Sudarno, 3 Desember 2018 (2018).

${ }^{35}$ Wawancara dengan bapak Sudarno, 3 Desember 2018.

${ }^{36}$ Muslich Masnur, Pendidikan Karakter:Menjawab Tantangan Krisis Multidimensional (Jakarta: Bumi Aksara, 2011).

${ }^{37}$ Wawancara dengan bapak Sudarno, 3 Desember 2018.

${ }^{38}$ Wawanara dengan ibu Hj. Lily, 14 Maret 2019 (2019).

${ }^{39}$ Wawancara dengan ibu Sri Harti Yulianti, 15 Maret 2019.

${ }^{40}$ Wawancara dengan ibu Sri Harti Yulianti, 15 Maret 2019.
} 
lahirnya sikap mandiri, dan disiplin dalam mengerjakan shalat berjemaah tepat waktu. Selain itu, mereka juga selalu bertanggung jawab dalam menjaga kebersihan dan kerapihan lingkungan. Khususnya untuk anak laki-laki di unit Cirendeu yang sudah sedikit besar, memiliki jadwal bersih-bersih rumah dan mereka melakukan tugas tersebut sesuai dengan yang dijadwalkan. Mereka bekerja sama membersihkan lingkungan, mulai dari kamar tidur, kamar mandi hingga halaman asrama.

Nilai religius lain yang ditanamkan di Yayasan Sayap Ibu Jakarta adalah bersikap toleransi. Manusia sebagai makhluk sosial membutuhkan orang lain untuk keberlansungan hidup. Tinggal di Indonesia dengan beragam ras, suku, agama dan budaya diharuskan untuk selalu menjaga kedamaian. Oleh sebab itu, Yayasan Sayap Ibu berusaha membina karakter anakanaknya untuk memiliki sikap toleransi. Dengan sikap tersebut, mereka dapat hidup rukun baik di mana mereka hidup dan tinggal saat ini ataupun di sekolah, di lingkungan masyarakat secara umum.

Toleransi atau sering disebut sebagai sikap menghargai perbedaan merupakan kunci untuk dapat hidup rukun dan menebarkan kasing sayang kepada orang lain. Nilai ini teraktualisasikan dalam kehidupan anak-anak terlantar yang terdapat di Yayasan Saya Ibu Jakarta. Karena anakanak yang terdapat di Yayasan tersebut tidak hanya terdiri dari anak yang bergama Islam, tetapi juga beragama lain seperti Kristen dan agama lain. Oleh karena itu, hidup toleran, rukun dan saling menghargai sudah menjadi karakter dan sikap mereka yang dimulai dari tempat di mana mereka tinggal.

\section{Metode Pembinaan Karakter}

Dalam melakukan pembinaan dan pembangunan karakter anak-anak terlantar, Yayasan Sayap Ibu Jakarta menggunakan tiga metode; pembiasaan, bercerita dan metode disipilin. Pertama, metode pembiasaan adalah cara untuk menciptakan suatu kebiasaan atau tingkah laku tertentu bagi anak didik. ${ }^{41}$ Armai Arief menegaskan bahwa metode pembiasaan merupakan sebuah cara yang dapat dilakukan untk membiasakan anak didik berfikir, bersikap dan bertindak sesuai dengan tuntutan ajaran agama Islam. ${ }^{42}$

Ciri khas metode pembiasaan adalah kegiatan yang berupa pengulangan berkal-kali dari suatu hal yang sama yang bertujuan agar asosiasi antara stimulus dengan suatu respon menjadi sangat kuat, atau supaya tidak mudah dilupakan. ${ }^{43}$ Dengan demikian metode pembiasaan merupakan cara yang efektif untuk menanamkan nilai-nilai karakter ke dalam jiwa anak.

Contoh penggunaan metode pembiasaan di Yayasan Sayap Ibu adalah kegiatan yang berkaitan dengan aktivitas keseharian dan keagamaan seperti merapikan dan membersihkan tempat tidur, memakai sepatu, manaruh baju kotor di tempat yang disediakan, mencuci piring setelah makan, menyapu, hingga mencuci menyetrika baju. Adapun kebiasaan dalam bidang keagamaan, misalnya anak-anak dibiasakan untuk selalu dibiasakan untuk selalu bangun mulai jam 04.00 menjelang shalat subuh. Setelah waktu shalat subuh tiba, mereka dibiasakan untuk melaksanakan shalat subuh jamaah. Agar anak-anak terjaga kesehatannya, maka setelah melaksanakan shalat subuh, mereka secara bersama-sama melakukan senam pagi, mandi, dan sarapan. Selanjutnya proses pendidikan formalnya dimulai dan berangkat mereka berangkat ke sekolah. ${ }^{44}$

Metode kedua adalah bercerita. Cerita dapat digunakan sebagai metode membina karakter, terutama pada anak TK atau prasekolah. Karena pada umumnya, anak lebih suka mendengar cerita. Menurut Jayanti, bercerita merupakan salah satu pemberian pengalaman bagi anak. Cerita merupakan kegiatan yang bersifat seni karena kaitannya dengan keindahan dan sandaran

\footnotetext{
${ }^{41}$ Ramayulis, Metodologi Pendidikan Agama Islam (Jakarta: Kalam Mulia, 2005).

${ }^{42}$ Arief Armai, "Pengantar Ilmu Dan Metodologi Pendidikan Islam” (Jakarta: Ciputat Press, 2002).

${ }^{43}$ Armai.

${ }^{44}$ Wawancara dengan bapak Sudarno, 3 Desember 2018.
} 
kepada kekuatan kata-kata yang dipergunakan untuk mencapai tujuan cerita. ${ }^{45}$ Bercerita merupakan seni menggunakan bahasa, vokalisasi dan atau gerakan fisik dan isyarat untuk mengungkapkan unsur-unsur dan gambaran dari dalam cerita. ${ }^{46}$

Isi cerita yang disampaikan juga harus memiliki unsur-unsur mendidik agar dapat memberikan perasaan gembira, lucu, menarik, inspiratif, motivasi dan mengasyikkan bagi anak. Metode bercerita ialah metode yang sangat disukai oleh anak-anak. Dengan menggunakan metode bercerita, anak akan banyak memperoleh informasi baru dari cerita yang dibacakan sehingga dapat meningkatkan kecerdasan dan membentuk karakter mereka. ${ }^{47}$

Penerapan metode bercerita di Yayasan Sayap Ibu dilakukan pada saat anak-anak sedang belajar bersama guru-guru ngajinya, yaitu pak Khojin dan pak Ubay. Berdasarkan pernyataan dari pak khojin: "bahwa anak-anak lebih suka ketika diceritai seperti kisah-kisah nabi dan dongeng anak, kemudian dari mereka ada yang bertanya dari hasil cerita yang mereka dengar dan saya menjawab pertanyaan tersebut.". ${ }^{48}$ Dari hasil bercerita yang berkaitan dengan kisah nabi dan kisah inspiratif inilah kemudian anak-anak dapat meniru akhlak baik para nabi dan mengaplikasikan dalam keseharian mereka. Seperti akhlak nabi yang suka menolong, rajin beribadah, bersih, rapi dan yang paling penting ialah berbuat baik pada semua orang, meskipun orang tersebut tidak menyukai kita.

Dan yang terakhir ialah pengaplikasian metode disiplin. Metode disiplin adalah suatu program yang didesain untuk membina anak agar menjadi anggota masyarakat yang bertanggung jawab, santun, cerdas. ${ }^{49}$ Metode disiplin menekankan pentingnya mengembangkan keterampilan hidup dan cara bersosialisasi berasaskan saling menghormati bagi anak dan orang dewasa. ${ }^{50}$ Disiplin mendorong anak untuk memiliki sikap menghargai waktu, mengerjakan segala sesuatu sesuai dengan jadwal waktunya masing-masing, dan membentuk karakter anak. Selain itu, metode ini juga melatih anak untuk mempunyai tanggung jawab, memiliki rasa hormat terhadap lingkungannya.

Penggunaan metode disiplin juga dibarengi dengan metode pembiasaan. Anak diajarkan disiplin dalam kegiatan yang sederhana terlebih dahulu, seperti disiplin waktu. Setiap hari yayasan telah memiliki jadwal rutinitas yang harus dilakukan anak setiap harinya, yaitu, ketika waktu sudah menunjukkan jam 4 subuh, maka mereka harus bagun, mandi, makan, sekolah hingga ketika jam 8 malam maka mereka sudah harus tidur lagi.

Demikian juga, sikap disiplin yang terkait dengan nilai-nilai agama seperti beribadah. Anakanak yang tinggal di asrama mematuhi dan melaksanakan jadwal yang telah dibuat oleh Yayasan. Contohnya ketika terdengar suara adzan subuh mereka selalu bangun dan mengerjalan shalat subuh. Bagi anak laki-laki, mereka melaksanakan shalat subuh berjemaah di asrama dan sebagian melaksanakan shalat berjemaah di masjid. Sementara itu, bagi anakanak perempuan, melaksanakan shalat di asrama.

Adapun pola pembinaan yang diterapkan di Yayasan Sayap Ibu adalah pembinaan secara demokratis. Pembinaan demokratis lebih mengutamakan adanya keterbukaan antara kedua pihak yakni pendidik atau orang tua dengan anak-anak. Sehingga ketika anak memiliki

\footnotetext{
${ }^{45}$ Luh Ayu Tirtayani Ni Made Sintia Wati, I Wayan Suatra, "Penerapan Metode Bercerita Berbasis Kearifan Lokal Untuk Mengembangkan Empati Anak Kelompok B1" 4, no. 2 (2016).

${ }^{46}$ Maitri Paramita; Luh Ayu Tirtayani; I G A Agung Sri Asri Ni Made, "Pengaruh Metode Bercerita Lokal Bali Terhadap Nilai Karakter Anak Kelompo B TK Gugus Melati Kecamatan Marga," Universitas Pendidikan Ganesha Jurusan Pendidikan Guru Pendidikan Anak Usia Dini 6, no. 3 (2018): 363-72.

${ }^{47}$ Ni Made.

${ }^{48}$ Wawancara dengan pak Khojin, 15 Maret 2019 (2019).

${ }^{49}$ Nelson, "Positive Dicipline: Creating Respectful Relationship At Home And School, Http:

Positivedisipline.Com," http: positivedisipline.com, n.d.

${ }^{50}$ Efi Ika Febriandari, "Penerapan Metode Disiplin Positif Sebagai Bentuk Pembinaan Pendidikan Karakter

Disiplin Anak SD," Seminar Nasional Pendidikan Dan Pembelajaran 20171 (2017),

http://journal.stkippgritrenggalek.ac.id/index.php/kid/article/view/132/82.
} 
problem, mereka akan bercerita secara leluasa dengan orang tuanya. Hal demikian sangatlah penting karena kebanyakan anak yang meresa takut dengan orang tuanya, mereka cenderung pasif. Selain itu anak-anak yang tidak memiliki orang tua atau anak tersebut terlantar maka mereka akan lebih merasa takut untuk bercerita. Kelebihan dari pembinaan demokratis ini salah satunya ialah memberikan apapun yang dibutuhkan oleh anak-anak namun dengan tetap memberikan kontrol atau pengawasan terhadap anak. Selain itu pembinaan ini juga mengutamakan aspek pendidikan dari pada hukuman. Walaupun demikian, pembinaan demokratis juga memberikan hukuman kepada anak dan tujuan dari pemberian hukuman untuk mendidik anak kemudian orang tua akan menjelaskan alasan dari diberikannya hukuman tersebut kepada anak.

Indikator dari pembinaan demokratis yaitu mampu menumbuhkan sikap menerima, responsif, berorientasi pada kebutuhan anak yang disertai dengan tuntutan, kontrol dan pembatasan. Sikap menerima, ditunjukan bahwa ketika anak-anak diperintah atau ketika dinasehati oleh pengasuhnya maka mereka mendengarkan dan melaksanakan perkataan tersebut. Hasil wawancara dengan ibu Lyli, selaku kepala asrama di Barito, bahwa ketika anak-anak diberitahu tentang hal-hal yang tidak boleh dilakukan maka mereka memahami dan melaksanakannya. ${ }^{51}$ Hal yang sama juga diaffirmasi oleh ibu Harti, selaku pengurus di unit Cirendeu yang mengatakan: "Alhamdulilah kebanyakan mereka sekarang nurut, mereka sudah mengerti sifat saya, bahwa maksud mama Harti marah bukan tanpa alasan, mama harti marah karena sayang kepada kalian. Nanti efeknya ke kalian kelak nanti dewasa. Kalian pintar untuk kalian sendiri. Mama harti tidak menginginkan apa-apa dari kalian." 52 Berdasarkan wawancara tersebut maka anak-anak terlantar yang dirawat oleh Yayasan Sayap Ibu memiliki sikap menerima yang baik disetiap individu.

Sedangkan responsif adalah adanya hubungan timbal balik antara masing-masing individu yang saling berkomunikasi dan bersifat menanggapi atau memberi tanggapan. Peneliti memperoleh data adanya sikap responsif pada diri anak-anak, yakni ketika peneliti bermain sambil bertanya kepada Mardi dan Ferdi. ${ }^{53} \mathrm{Hal}$ ini dibuktikan ketika peneliti bertanya kepada keduanya, kemudian mereka bertanya balik kepada peneliti. ${ }^{54}$ Perilaku seperti ini juga tercermin pada Riyan dan Mulya ketika sesi wawancara. Dengan demikian anak-anak di Yayasan Sayap Ibu juga memiliki sikap responsif terhadap temannya maupun orang lain atau tamu yang berkunjung ke yayasan. Menurut pengakuan dari Sudarno bahwa "anak-anak panti merasa sangat bahagia jika banyak tamu yang berjunkung ke Yayasan, karena mereka ada yang mengajak bermain bersama, ada yang menjenguk mereka dan itu semua merupakan kebahagiaan tersendiri bagi anak-anak."55

Menurut Komaruddin Hidayat, ada tiga pilar utama kebahagiaan; keluarga yang baik dan harmonis, pekerjaan yang baik, dan memiliki teman dan komunitas yang baik. Berdasarkan pada tiga pilar ini, secara psikologis, anak-anak terlantar akan merasakan kebahagiaan karena merasa memiliki teman dan sekaligus keluarga. ${ }^{56}$ Sebagaimana disebutkan di atas, bahwa anakanak terlantar adalah anak-anak yang tidak memiliki keluarga [orang tua], baik karena meninggal atau ditelantarkan secara sengaja baik karena bercerai, lahir dari hasil hubungan haram, maupun faktor-faktor lain.

Indikator terakhir yaitu berorientasi pada kebutuhan anak yang disertai dengan tuntutan, kontrol dan pembatasan. Maksud dari indikator ini ialah pengasuh yayasan menyediakan dan memberikan kebutuhan yang anak-anak perlukan. Seperti memenuhi hak anak untuk bermain,

\footnotetext{
${ }^{51}$ Wawanara dengan ibu Hj. Lily, 14 Maret 2019.

52 Wawancara dengan ibu Sri Harti Yulianti, 15 Maret 2019.

${ }^{53}$ Wawancara dengan Mardi, 15 Maret 2019 (2019).

${ }^{54}$ Wawancara dengan Ferdi, 15 Maret 2019 (2019).

${ }^{55}$ Wawancara dengan bapak Sudarno, 3 Desember 2018.

${ }^{56}$ Hidayat, Psikologi Kebahagiaan: Merawat Bahagia Tiada Akhir.
} 
hak anak untuk bersekolah, hak-hak kesehatan dan sebagainya. ${ }^{57}$ Tetapi, dalam pemberian kebutuhan tersebut dibarengi juga dengan pengawasan, kontrol, pembatasan dan tuntutan yang harus dilakukan anak-anak. Seperti hasil wawancara dengan ibu Harti, setiap pagi anak-anak dibangunkan jam 04.00 untuk nyapu dan mengepel. Mereka memiliki tanggung jawab dan tugas masing-masing”. Jika mereka tidak melaksanakan tugas dan tanggungjawabnya, maka mereka tidak akan mendapat uang saku. ${ }^{58}$ Hal tersebut dikonfirmasi oleh pak Sudarno, yakni yayasan memberikan hak untuk mereka, tetapi juga ada pembatasan dalam arti membagi waktu-waktu mereka agar seimbang dan mereka dapat disiplin waktu. ${ }^{59}$ Dengan sanksi tersebut, maka mereka akan terbiasa untuk selalu bertanggungjawab.

\section{KESIMPULAN}

Berdasarkan pemaparan hasil penelitian dan analisa di atas, penelitian menyimpulkan bahwa Yayasan Sayap Ibu Cabang Jakarta telah hasil membina dan membangun karakter anak-anak terlantar. Pendidikan Karakter berbasis nilai religius, menurut Yayasan Sayap Ibu adalah pendidikan yang sesuai dengan ajaran agama Islam atau agama-agama yang dianutnya dan sangat efektif dalam proses pembinaan.

Strategi yang digunakan Yayasan Sayap Ibu Cabang Jakarta ialah dengan mengajarkan pendidikan etika dan kegiatan keagamaan. Proses tersebut dilakukan dengan menggunakan metode pembiasaan, metode disiplin, dan metode bercerita. Metode tersebut telah menumbuhkan karakter yang mandiri, disiplin, jujur, tanggungjawab dan toleransi. Adapaun komunikasi yang digunakan dalam melakukan pembinaan adalah metode komunikasi yang demokratis.

\section{DAFTAR PUSTAKA}

“178 Bayi Dibuang Ke Jalan Sepanjang 2017." http:tribunnew.com, 2018.

“2018, Kasus Pembuangan Bayi Meningkat.” http:medanbisnisdaily.com, 2019.

“4.1 Juta Anak Terlantar." Beritasatu.com, 2018.

Agus, Wibowo. Pendidikan Karakter: Strategi Membangun Karakter Bangsa Berperadaban. Yogyakarta: Pustaka Pelajar, 2012.

Ali, Muhammad. Memahami Riset Prilaku Sosial. CV Pustaka Cendekia Utama, 2011.

Amran Hassan, Fatimah Yusooff, Khadijah Alavi. "Pengaruh Faktor Kesepaduan

(Kefungsian Keluarga) Dan Kemahiran Keibubapaan Terhadap Kesejahteraan Psikologi

Dalam Kalangan Ibu Bapa Dan Anak.” Sains Humanika 3, no. 1 (2014): 99-105.

Andayani, Abdul Majid dan Dian. Pendidikan Karakter Perspektif Islam. Bandung: PT Remaja Rosdakarya, 2011.

Armai, Arief. "Pengantar Ilmu Dan Metodologi Pendidikan Islam.” Jakarta: Ciputat Press, 2002.

Asysyifa, Siti. Faktor Yang Menyebabkan Penelantaran Anak. Salatiga: Universitas Kristen Satya Wacana, 2017.

"Badan Pusat Statistik Provinsi Jawa Barat." http: jabar.bps.go.id, 2018.

Budiyono, Kabul. Pendidikan Pancasila Untuk Perguruan Tinggi. Bandung: Alfabeta, 2016.

“Dinas Sosial DKI Jakarta, Data Titik Rawan Anak Terlantar Tahun 2018-2019." http: data.jakarta.go.id, 2019.

Eko Setiawan, Nurliana Cipta Apsari, and Santoso Tri Raharjo. "Pengangkatan Anak Balita Terlantar." Sosio Informa 5, no. 1 (2019): 25-37. https://doi.org/10.33007/inf.v5i1.1622.

Endang Mulyaningsih, Indrati, Pengaruh Interaksi Sosial Keluarga, Motivasi Belajar, Dan

Kemandirian Belajar terhadap Prestasi Belajar, Indrati Endang Mulyaningsih FKIP

\footnotetext{
57 Wawancara dengan bapak Sudarno, 3 Desember 2018.

${ }^{58}$ Wawancara dengan ibu Sri Harti Yulianti, 15 Maret 2019.

${ }^{59}$ Wawancara dengan bapak Sudarno, 3 Desember 2018.
} 
Universitas Veteran Bangun Nusantara Sukoharjo Jl Letjen Sudjono Humardani No, and Kampus Jombor Sukoharjo. "The Influence of Social Interaction of Family Relationship, Achievement Motivation, and Independent Learning on Learning Achievement." Jurnal Pendidikan Dan Kebudayaan 20, no. 4 (2014): 441-51.

Febriandari, Efi Ika. "Penerapan Metode Disiplin Positif Sebagai Bentuk Pembinaan Pendidikan Karakter Disiplin Anak SD." Seminar Nasional Pendidikan Dan Pembelajaran 20171 (2017).

http://journal.stkippgritrenggalek.ac.id/index.php/kid/article/view/132/82.

Gulo, Dali. Kamus Psikologi. Bandung: Tonis, 1982.

Hamdani, dkk, Hamied. Pendidikan Karakter Perspektif Islam. Bandung: Pustaka Setia, 2013.

Hidayat, Komaruddin. Psikologi Kebahagiaan: Merawat Bahagia Tiada Akhir. Jakarta: Noura Books, 2015.

Hyoscyamina, Darosy Endah. "Peran Keluarga Dalam Membangun Karaker Anak." Marine Mining 10, no. 2 (2011).

Kaelan. Metode Penelitian Agama Kualitatif Interdisipliner. Jogjakarta: Paradigma, 2010.

Kementerian Sosial Dalam Angka Pembangunan Kesejahteraan Sosial. Jakarta: Kementerian Sosial Republik Indonesia, Pusat Data Dan Informasi Kesejahteraan Sosial, 2012. perpustakaan.bappenas.go.id.

Masnur, Muslich. Pendidikan Karakter:Menjawab Tantangan Krisis Multidimensional. Jakarta: Bumi Aksara, 2011.

Nelson. "Positive Dicipline: Creating Respectful Relationship At Home And School, Http: Positivedisipline.Com,." http: positivedisipline.com, n.d.

Ni Made, Maitri Paramita; Luh Ayu Tirtayani; I G A Agung Sri Asri. "Pengaruh Metode Bercerita Lokal Bali Terhadap Nilai Karakter Anak Kelompo B TK Gugus Melati Kecamatan Marga." Universitas Pendidikan Ganesha Jurusan Pendidikan Guru Pendidikan Anak Usia Dini 6, no. 3 (2018): 363-72.

Ni Made Sintia Wati, I Wayan Suatra, Luh Ayu Tirtayani. "Penerapan Metode Bercerita Berbasis Kearifan Lokal Untuk Mengembangkan Empati Anak Kelompok B1” 4, no. 2 (2016).

Nugroho, Puspo. "Internalisasi Nilai-Nilai Karakter Dan Kepribadian Mahasiswa Pendidikan Agama Islam Melalui Pendekatan Humanis-Religius." Edukasia : Jurnal Penelitian

Pendidikan Islam 12, no. 2 (2017): 355. https://doi.org/10.21043/edukasia.v12i2.2491.

Ramayulis. Metodologi Pendidikan Agama Islam. Jakarta: Kalam Mulia, 2005.

Robert L. Balker. The Social Work Dictionary. Washington DC: National Association of Social Workers (NASW) Press, 1999.

Siti Anisah, Ani. "Pola Asuh Orang Tua Dan Implikasinya Terhadap Pembentukan Karakter Anak." Jurnal Pendidikan Universitas Garut 05, no. 01 (2011): 70-84.

https://journal.uniga.ac.id/index.php/JP/article/viewFile/43/43.

Sjarkawi. Pembentukan Kerpibadian Anak. Jakarta: Bumi Aksara, 2008.

Suyanto. "Urgensi Pendidikan Karakter, Direktorat Pendidikan Dasar Kementrian Pendidikan Nasional." Http: Www.Mandikdasmen.Depdiknas.Go.Id, 2019.

Suyanto, Bagong. Masalah Sosial Anak. Jakarta: Kencana Prenada Media Group, 2010.

Syarbin, Amirulloh. "Model Pendidikan Karakter Dalam Keluarga." Jakarta: PT Elex Media Komputindo, 2014.

Tampubolon, Daulat P. Perguruan Tinggi Bermutu: Paradigma Baru Management

Pendidikan Tinggi Menghadapi Tantangan Abad Ke 21. Jakarta: PT Gramedia Pustaka Utama, 2001.

"Visi Misi Yayasan Sayap Ibu." http://sayapibujakarta.org, n.d.

Wawanara dengan ibu Hj. Lily, 14 Maret 2019 (2019). 
Wawancara dengan bapak Sudarno, 3 Desember 2018 (2018).

Wawancara dengan Ferdi, 15 Maret 2019 (2019).

Wawancara dengan ibu Sri Harti Yulianti, 15 Maret 2019 (2019).

Wawancara dengan Mardi, 15 Maret 2019 (2019).

Wawancara dengan pak Khojin, 15 Maret 2019 (2019).

Zubaidi. Desain Pendidikan Karakter: Konsep Dan Aplikasinya Dalam Lembaga Pendidikan. Jakarta: Kencana, 2011. 